\title{
Variability and connectivity of plaice populations from the Eastern North Sea to the Western Baltic Sea, and implications for assessment and management
}

Ulrich, Clara; Boje, Jesper; Cardinale, Massimiliano; Gatti, Paul; le Bras, Quentin; Andersen, Michael; Hansen, Jakob Hemmer; Hintzen, Niels T.; Jacobsen, Jonathan B.; Jonsson, Patrik

Total number of authors:

16

Published in:

Journal of Sea Research

Link to article, DOI:

10.1016/j.seares.2013.04.007

Publication date:

2013

Link back to DTU Orbit

Citation (APA):

Ulrich, C., Boje, J., Cardinale, M., Gatti, P., le Bras, Q., Andersen, M., Hansen, J. H., Hintzen, N. T., Jacobsen, J. B., Jonsson, P., Miller, D. C. M., Eg Nielsen, E., Rijnsdorp, A. D., Sköld, M., Svedäng, H., \& Wennhage, H. (2013). Variability and connectivity of plaice populations from the Eastern North Sea to the Western Baltic Sea, and implications for assessment and management. Journal of Sea Research, 84, 40-48.

https://doi.org/10.1016/j.seares.2013.04.007

\section{General rights}

Copyright and moral rights for the publications made accessible in the public portal are retained by the authors and/or other copyright owners and it is a condition of accessing publications that users recognise and abide by the legal requirements associated with these rights.

- Users may download and print one copy of any publication from the public portal for the purpose of private study or research.

- You may not further distribute the material or use it for any profit-making activity or commercial gain

- You may freely distribute the URL identifying the publication in the public portal 


\title{
Variability and connectivity of plaice populations from the Eastern North Sea to the Western Baltic Sea, and implications for assessment and management.
}

\author{
Clara Ulrich ${ }^{\mathrm{a}}$, Jesper Boje ${ }^{\mathrm{a}}$, Massimiliano Cardinale ${ }^{\mathrm{b}}$, Paul Gatti ${ }^{\mathrm{a}}$, Quentin LeBras ${ }^{\mathrm{a} 1}$, Michael Andersen ${ }^{\mathrm{c}}$, \\ Jakob Hemmer-Hansen ${ }^{d}$, Niels T. Hintzen ${ }^{e}$, Jonathan B. Jacobsen ${ }^{c}$, Patrik Jonsson ${ }^{b}$, David C.M. Miller ${ }^{e}$, \\ Einar E. Nielsen ${ }^{d}$, Adriaan D. Rijnsdorp ${ }^{e}$, Mattias Sköld, Henrik Svedäng ${ }^{b}$, Håkan Wennhage ${ }^{b}$ \\ ${ }^{a}$ Technical University of Denmark, National Institute for Aquatic Resources (DTU Aqua), Charlottenlund Castle, \\ 2920 Charlottenlund, Denmark \\ ${ }^{b}$ Swedish University of Agricultural Sciences (SLU), Department of Aquatic Resources, Institute of Marine Research, \\ Turistgatan 5, SE-453 30 Lysekil, Sweden \\ 'Danish Fishermen's Producers' Organization (DFPO), Nordensvej 3, Taulov, 7000 Fredericia \\ ${ }^{\mathrm{d}}$ Technical University of Denmark, National Institute for Aquatic Resources (DTU Aqua), Vejlsøvej 39, 8600 \\ Silkeborg \\ ${ }^{\mathrm{e}}$ Institute for Marine Resources and Ecosystem Studies (IMARES), Wageningen University \& Research Centre \\ (WUR), P.O. Box 68, 1970 AB IJmuiden, The Netherlands
}

\begin{abstract}
An essential prerequisite of sustainable fisheries is the match between biologically relevant processes and management action. Various populations may however co-occur on fishing grounds, although they might not belong to the same stock, leading to poor performance of stock assessment and management. Plaice in Kattegat and Skagerrak have traditionally been considered as one stock unit. Current understanding indicates that several plaice components may exist in the transition area between the North Sea and the Baltic Sea. A comprehensive review of all available biological knowledge on plaice in this area is performed, including published and unpublished literature together with analyses of commercial and survey data and historical tagging data. The results suggest that plaice in Skagerrak is closely associated with plaice in the North Sea, although local populations are present in the area. Plaice in Kattegat, the Belts Sea and the Sound can be considered a stock unit, as is plaice in the Baltic Sea. The analyses revealed great heterogeneity in the dynamics and productivity of the various local components, and suggested for specific action to maintain biodiversity.
\end{abstract}

Keywords: cod, distribution, Gadus morhua, growth, haemoglobin, physiology

*Corresponding author: Dr. Clara Ulrich, DTU Aqua, Tel +45 2115 74 86; clu@aqua.dtu.dk

Article first published online: 24 April 2013

Please note that this is an author-produced PostPrint of the final peer-review corrected article accepted for publication. The definitive publisher-authenticated version can be accesses here: http://dx.doi.org/10.1016/j.seares.2013.04.007 


\section{Introduction}

An essential prerequisite of sustainable fisheries is the match between biologically relevant processes and management action (Reiss et al., 2009). Management however, is often undertaken at the scale of large hydrographical basins with fixed administrative boundaries, which can often mismatch the putative ecological and/or genetic structure of the marine populations. Even when known and acknowledged (see e.g. review by Reiss et al., 2009), such a mismatch can often not be easily solved. This is partly due to the inertia inherent in fisheries management and its set of conflicting objectives, but partly also because the exact characterization and quantification of the mismatch is a difficult task (ICES 2011b).

Fish species show complex life cycles that comprise ontogenic habitat segregation. A population can only sustain itself when the habitats are connected and the fish can close the life cycle (Sinclair, 1988, Rijnsdorp et al., 2009). Fish of different populations may mix during feeding while they segregate during the spawning period. Hence, it is important to know if the fish in a certain area belong to a single panmictic population, or belong to different populations (Metcalfe, 2006; Volckaert 2013). Stock assessment usually builds on catches from a given area, and if different genetic populations are simultaneously present within this area, such a procedure will produce an overall picture of stock dynamics, which might not reflect actual trends within these individual populations (Kell et al., 2009). All individual components should however be maintained and their dynamics monitored to ensure the overall sustainability of the stock.

For some species, such as herring, it has been possible to monitor the relative proportion of each population in an area (e.g. Clausen et al., 2007, Bierman et al., 2010, ICES, 2011b). But in most cases it is not possible, and fish stocks are usually assessed ignoring the underlying structure of sub-populations. This may increase the risk of depletion of local stocks and stock collapse (Hilborn et al., 2003, Kell et al., 2009, Ying et al., 2011).

The European plaice (Pleuronectes platessa, Pleuronectidae) is predominantly distributed within the North Sea but extends to adjacent waters. Plaice stock structure comprises different spawning components, which separate during spawning and mix during feeding. Juveniles of different spawning components mix also partly on nursery grounds (Hunter et al., 2004, Kell et al., 2004, Hufnagl et al., 2012). In spite of the assumed connectivity between components, plaice abundance is assessed and managed as a suite of ten discrete stock units from the West of Ireland to the Eastern Baltic Sea (ICES, 2010). Only for the eastern English Channel is the connectivity with both the Western English Channel and the North Sea coarsely accounted for in stock assessment and advice (ICES, 2011a). Noticeably, although several different spawning components are acknowledged, Hoarau et al. (2002, 2004) found only weak genetic differentiation between the North Sea-Irish Sea, Norway, the Baltic and the Bay of Biscay using mt-DNA and microsatellite genetic markers. On the Eastern side of the North Sea, a single plaice stock has historically been defined in the transition area to the Baltic Sea, in ICES Division IIIa (covering two sub-divisions, Skagerrak (IIIa North) and Kattegat (IIIa South)). This area is characterised by a great heterogeneity of hydrographical conditions, with a very steep salinity gradient and important mainstream currents (Danielssen et al, 1997, Figure 1). The assessment of this 
stock by the International Council for the Exploration of the Sea (ICES) has increasingly been deemed as unreliable and the annual advice for future catch opportunities has thus long been given without sound scientific basis (ICES, 2010). This has important political and socio-economic consequences. Although plaice is not among the highest valued species in the area, it is nevertheless targeted by a coastal fishery along the Danish Northwestern Jutland coast. It enters also a mixed trawl fishery together with cod and Nephrops. Thus, the scientific inability to deliver a robust stock assessment in area IIIa is a concern for the sustainability of the stock itself but also for the local fishery that exploits it. In addition, the lack of agreed assessment is an institutional barrier against fisheries ecolabelling, which has created mistrust and frustration among stakeholders. Overall, there is an urgent need to improve the whole governance scheme for this stock.

Over the years, a number of initiatives have been taken within ICES to improve the assessment of this stock (e.g. ICES, 2006), but with limited success. A major problem is the difficulty in tracking cohorts in the catch-atage matrix. This study investigates the potential sources of uncertainty and variability driving this issue. It presents a comprehensive literature review of the biology of plaice in the area, complemented by an analysis of recent commercial catch and survey data and historical tagging data, that may throw light on the stock structure in the transition area. A significant part of the relevant information was found in the grey literature including ICES working group reports and unpublished master theses and laboratory studies. This synthesis allows us to produce a revised picture of the plaice stock structure from the Eastern North Sea to the Baltic Sea, and we discuss the implications for sustainable management.

\subsection{Distribution}

\subsubsection{Spawning and egg/larvae drift}

Spawning in the Kattegat usually occurs in late February and early March at depths between 30 and 40 meters (Nielsen et al., 2004a) and in temperatures at about 4 degrees Celsius (Simpson, 1959). The main plaice spawning grounds are located in the south-western part of the Kattegat (Johansen, 1912; Poulsen, 1939, Ulmestrand, 1992; Nielsen et al., 1998; 2004a). Spawning sites have also been indicated along the Swedish Kattegat coast (Trybom, 1908; Molander, 1923). Modelling studies have indicated that the Swedish coast was formerly occupied by extensive aggregations of adult fish during spawning time, and that the reduction of this component is mostly a recent feature (Cardinale et al., 2011).

The evidence of spawning in the Skagerrak is less clear and available information is inconsistent or sometimes contradictory. Johansen (1912) found only few eggs and larvae in the Skagerrak and therefore considered spawning in Skagerrak unimportant. The egg density in the North Sea off the north coast of Denmark was observed to be low by Taylor et al. (2007), but high by Munk et al. (2009). Potential inflow of North Sea eggs and larvae in Skagerrak is corroborated by particle drift modelling in the North Sea (Hufnagl et al., 2012), which predicts an inflow of North Sea water and thereby eggs and larvae into Skagerrak during spring. This 
pattern could be expected to be more pronounced nowadays, in the current period of record-high North Sea plaice abundance (ICES, 2012a) and northerly shift in North Sea plaice distribution (Engelhard et al., 2011). However, low to moderate spawning activity was noticed in the south-western part of the Skagerrak by Molander (1923), Ulmestrand (1992) and Nielsen and Bagge (1985). The modelled results by Cardinale et al. (2011) also suggest that aggregations of adult fish during $1^{\text {st }}$ quarter may occur along the Danish North coast. In addition, anecdotal information from the Danish fishing industry has reported large catches of spawning females along the Danish Skagerrak coast. However, there are very little records of spawning or spent females in Skagerrak in IBTS spring data (Gatti, unpublished ${ }^{2}$ ).

This information indicates therefore that spawning in the Skagerrak is likely to occur, but a significant part of the eggs and larvae settling in shallow waters in the Skagerrak are considered to originate from the North Sea stock. This drift is reinforced during windy winters, where larvae may drift further into the Kattegat (Poulsen 1939, Nielsen et al., 1998).

Beyond the area IIIa, spawning is likely to take place in the Belt Sea and in the Sound (Svedäng et al. 2004). Free-floating eggs are found in the deeper basins in the southern Baltic Sea (Nissling et al. 2002). Both spermatozoa and eggs are adapted to the low salinity conditions that prevail in the southern Baltic Sea.

\subsubsection{Nurseries}

Plaice are dependent on shallow $(0-3 \mathrm{~m})$ sediment substratum as nursery grounds during their early juvenile stage (Gibson 1999). For plaice, variation in year-class strength is generated during the pelagic stages and subsequently dampened during the early juvenile stage indicating that density dependent processes are acting on the nursery grounds (van der Veer 1986, Beverton 1995). These nurseries are important for the population dynamic since a relationship between the nursery size and the population abundance has been hypothesized (Rijnsdorp et al., 1992; van der Veer et al., 2000).

In the Skagerrak-Kattegat area potential plaice nursery grounds are present along the Swedish west coast and along the Danish Kattegat coast (Wennhage et al., 2007). The absence of tides in the area makes the physical condition in the shallow nursery areas benign and stable (Gibson et al. 1998), but excludes the possibility for selective tidal transport as a mechanism for plaice larvae to reach nursery grounds. The Swedish Skagerrak coast is rocky, but contains many small nursery grounds within the complex archipelago. The inter-annual variation in supply of larvae to the Eastern Skagerrak nursery grounds is correlated to prevalence of onshore wind (Pihl 1990, Nielsen et al., 1998). Growth rate is negatively correlated and mortality positively correlated to settlement density in the area (Pihl et al. 2000). The Kattegat has more of an open coast with plaice nursery habitats fringing the coast. Juvenile recruitment in the nursery areas along the southern part of the Danish east coast drift mainly from the spawning areas in southern Kattegat (Nielsen et al. 1998).

\footnotetext{
${ }^{2}$ Gatti, 2011. Source of uncertainties in the catch-at-age matrix of the Illa plaice stock. Bachelor internship report, Agrocampus Ouest, Rennes, France. Unpublished.
} 
The distribution of adults can be inferred from the commercial fishery data and the scientific surveys. The fishery operates year round in the area IIIa, without strong seasonal patterns. The most productive area is the Danish North coast from the North Sea boundary to the most Northerly harbour of Skagen, and there is a continuum of catches from there to the North Sea (Figure 2). Catches in the Western Skagerrak component normally constitute at least $90-95 \%$ of the total Skagerrak catches. There are less catches in the North of Kattegat and along the Swedish coast of Skagerrak. The fishery is also important in the Southwestern Kattegat and Belt Sea, and then in the Baltic Sea around the island of Bornholm. During spawning season, adults aggregations recorded by surveys reflect that general pattern (Cardinale et al., 2011). Plaice is primarily caught by targeted Danish fisheries using selective gears such as gillnets and Danish seine, and also in demersal trawl mixed fisheries. Overall, trends in Danish landings in Skagerrak are comparable to those in the neighbouring central North Sea (subdivision IVb), whereas landings in Kattegat have continuously decreased (Figure 3). Beyond the effect of external factors linked to regulations and alternative fishing opportunities, such trends might also reveal a closer coupling in the dynamics of the plaice populations in Skagerrak and North Sea than with the Kattegat.

\subsection{Migrations}

Nielsen et al. (unpublished ${ }^{3}$ ) compiled an extensive collection of historical (1903-1964) Danish plaice tagging experiments in the fishing grounds around Denmark, where about 13000 fish were recaptured from an initial release of about 40000 individuals. The tagging started in 1903-4 in Kattegat, Skagerrak and the North Sea, while the Belt Sea taggings was initiated in 1922. The overall dataset is patchy and unbalanced since the successive taggings experiments were performed independently from each other, but represents nevertheless a new source of information of potential interest. Releases were performed in all seasons but mainly concentrated in March-May and September-November. For the analyses of migrations between areas, recaptures were calibrated with nominal landings from ICES annual statistics, as measures of fishing effort were not available for the time series.

These Danish tagging data revealed stable migration pattern over the years. In general limited movements were recorded, especially in the Belt, Western Baltic, Kattegat and North Sea, where up to $90 \%$ of the fish were recaptured in the same area as they were released (Figure 4). In total, plaice migration into and out of the entire management area IIIa was in the range $5-10 \%$ of the tagged individuals. However most tagged fish were recaptured within the tagging year, and only $18 \%$ of the tags had stayed more than one year at sea. Remote recaptures within the year is indicative of seasonal migration, whereas remote recapture after more than year may also reflect ontogenic migration.

Considering all tags, the recaptures from the Skagerrak releases exhibited the highest rates of movement $(>40 \%)$ indicating that this area is a transitional area. There was an easterly net within-year flow towards the

\footnotetext{
${ }^{3}$ Nielsen, E., Boje, J., and Nicolaisen. H. Plaice tagging in Danish waters 1903-1964. Working Document to ICES (2006)
} 
North of Kattegat which could reflect: (1) a spawning migration of a Skagerrak stock towards spawning around Skagen peninsula as suggested by Cardinale et al. (2011) or (2) a summer migration of fish spawning in the westerly areas or in the North Sea towards feeding grounds in Skagerrak. Relative little mixing occured between fish in the northern and southern Kattegat. However, southern Kattegat seems more connected to the Belts and the Baltic. Considering only the tags recaptured after more than one year, the patterns appeared quite different (Figure 4). No eastwards migrations were observed in Skagerrak and Kattegat, but conversely a significant amount of fish released there were caught in the North Sea.

Swedish tagging experiments between 1903 and 1909 of plaice on the Swedish Kattegat coast are consistent with these patterns. They indicated a resident adult population (Trybom, 1905; 1908; Molander, 1944), although a significant proportion of the juvenile fish tagged in the northern Kattegat migrated towards western Skagerrak and the North Sea as they became older.

In the Skagerrak, tagging studies on the Swedish Skagerrak coast in the 1920s (Molander, 1923), and in the 1960s (Jacobsson, 1982), showed that the resident component was very small (estimated by maturity examinations), indicating that the coastal zone may function as a nursery area for offshore spawning stocks. At ages 2-4 years, maturing fish left the coast and swam towards the western Skagerrak and to various locations in the North Sea. It was noted that the size and age at which the plaice left their coastal nursery grounds varied systematically between fjords. It should also be observed that some tagged fish migrated for spawning to the northern part of the Swedish Kattegat coast (Molander, 1923).

Additionally, three tagging experiments were conducted in the Baltic Sea (SD 25) on the Swedish east coast between 1908 and 1909. In spite of low recapture rates, the experiments indicated rather stationary behaviour with no reported recaptures beyond the western Baltic (SD 24) (Trybom, 1911). This is also consistent with the Danish tagging data.

Parasite data corroborated the results of the tagging experiments and showed that adult plaice residing in the Skagerrak between spring and autumn may migrate into the North Sea during the spawning period in winter (van Banning et al., 1978). Skagerrak plaice was characterised by a high infestation rate with the parasite Myxabolis aeglefinus. Infestation rate was high throughout the year in Skagerrak plaice (>30\%), but showed both a clear seasonal and latitudinal trend in North Sea areas. Infestation rates were highest during the spawning period in the North Sea increasing from a maximum of about $1 \%$ in the Southern Bight and Flamborough spawning grounds, to $5-10 \%$ in the German Bight and $10 \%$ in the Fisherbank spawning ground. It is important to notice that all these tagging data were old (up to 100 years) and may no longer be representative for the current situation since population dynamics may have changed in relation to the environmental conditions as shown in Cardinale et al. (2011). Therefore, we conclude that these older data provide a useful overall picture of the putative population structure, but do not allow any quantification of its current dynamics. 


\subsection{Genetic structure}

A number of studies have investigated the genetic population structure of plaice across its Northern European distribution (Hoarau et al. 2002, 2004; 2005; Watts et al. 2010: Was et al. 2010). In particular, transitions have been studied through samples from the North Sea, Western Baltic and Eastern Baltic. However, samples from IIIa have not been included in any of the studies. Generally, these studies have found very limited genetic structure using both nuclear microsatellites and mtDNA SSCP (Single Strand Conformation Polymorphism) analysis, the only exceptions being the very distinct off shelf populations from Iceland and Faeroe Islands (Hoarau et al. 2002; Was et al. 2010). Within the North Sea region, Hoarau et al. (2002; 2005) found no evidence of genetic structuring of populations, while they found that Western Baltic plaice were weakly distinguishable from North Sea/Irish Sea plaice using mtDNA analysis. Meanwhile, using microsatellites did not allow distinguishing between Baltic and North Sea populations (Was et al., 2010).

These results differ from recent genetic studies of other marine fish (including other flatfish such as flounder and turbot) in the transition area between the North Sea and the Baltic Sea, that revealed a relatively high degree of population structuring with a gradual genetic change correlating with the changes in environmental variables, and salinity in particular (Limborg et al., 2009, Nielsen et al. 2004b, Hemmer-Hansen et al. 2007).

\subsection{Growth and reproduction}

Age-Length Keys (ALK) by sex and area during first quarter from 2005 to 2010 were combined from the Danish harbour samples and the IBTS data (see Supplementary Online Material), and von Bertalanffy curves were fitted using nls function in R (Figure 5). The ALKs are rather flat and spread, with overlapping distribution of ages across length. This variability is not a priori considered to reflect the actual uncertainty in the otolith aging itself, since there is a fair amount of consistency across the age interpretation of various experienced age readers (L. Worsøe Clausen, pers. Com.), especially for the younger ages. Rather, this reflects that the individual variability in growth is large and blurs the signal in data, contributing to the lack of cohort tracking in the catch-at-age matrix. This individual variability could be linked to either the heterogeneity of local hydrographical conditions impacting growth, and/or to catches originating from different populations. Differences in growth patterns by sex are marked; however, there are average differences in growth across areas only for males.

First quarter IBTS data from 2005 to 2010 were used to estimate maturity ogives in Kattegat and Skagerrak (Figure 6). Every fish which had a maturity stage greater than or equal to 2 was considered to be mature. Maturity differences were found between Skagerrak and Kattegat. As Rijnsdorp (1989) showed in the North Sea, there is an increase of age at $50 \%$ maturity (A50) from South to North. On average, a Kattegat plaice matures earlier than a Skagerrak one. 


\section{Discussion}

\subsection{Synthesis}

This comprehensive work of both literature review of published and unpublished studies as well as compilation and analysis of various data suggest a complex picture of plaice stock structure between the North Sea and the Baltic Sea. The information available is often sporadic, fairly old, and sometimes inconsistent or contradictory. Consequently, the linkages between units cannot be quantified nor precisely mapped.

However, some broad and qualitative patterns in plaice distribution and population dynamics have emerged. The area IIIa is highly heterogeneous in terms of hydrographical conditions, and it is hypothesised that salinity, currents and wind are potentially strong drivers of the dynamics of growth and populations. There is evidence of spawning by local populations at both boundaries of the area in the Western Skagerrak and the Southwestern Kattegat, but the inflow of eggs and larvae from the North Sea is expected to be important. The importance of the Swedish coast as a spawning area has decreased to a very low level (Cardinale et al., 2011), but this area still acts as important nursery grounds connected to both the local and the North Sea spawning grounds. A westerly homing behaviour of the North Sea juveniles has been observed through the tagging studies, whereas some both-ways seasonal adult migration has been recorded at both boundaries and also within Skagerrak. The Northern Kattegat (around the Island of Læsø) seems to act as an internal border between Skagerrak and Kattegat, with lesser fish and fishing density and limited exchanges. Although there is a continuum of plaice fishing from the North Sea to the Baltic Sea, the main fishery is primarily located towards the North Sea boundary. Similar trends in catch rates and hydrographical features across this boundary suggest also that the increasing North Sea stock may extend beyond the administrative boundary.

In summary, catches in the Western Skagerrak are therefore expected to be a mix of: i) adult North Sea plaice whose distribution extends beyond the North Sea boundary; ii) juvenile North Sea plaice that hatched in area IIIa and return to the North Sea to spawn; iii) local populations spawning along the Danish coast. In the area further East towards the Swedish coast and Northern Kattegat, fish densities have dropped to historically low levels and catches are low. This area doesn't seem to beneficiate from North Sea adults migrating into the Kattegat. Therefore, catches in this area may be mostly constituted of categories ii) and iii) above. Finally, catches in the Kattegat (South from Læsø) and in the Belt Sea may mostly be constituted of local populations, although some North Sea juveniles (category ii) may still have settled in these more southerly areas.

This complex picture of stock structure, together with the diversity of local hydrographical conditions, complicates the study of the population dynamics in the area. Scientific data from surveys and harbour sampling show great individual variability of growth patterns, and extrapolating from these samples to the stock level produces a poor tracking of the cohorts. 


\subsection{Implications for stock assessment and management}

The information on biology and fishery of plaice in IIIa and adjacent waters reviewed above, supports a revision of the delineation of plaice stocks and corresponding management areas into three stocks (ICES 2012a, b). In terms of stock assessment, plaice in the Skagerrak is shown to be more closely associated with North Sea plaice. it seems therefore sensible to include Skagerrak in the North Sea stock assessment in spite of the evidence for a spatial structure in the Skagerrak. The second stock is found further south and comprises the plaice in Kattegat (SD 21), Belts (SD 22) and Sound (SD 23). The third plaice stock is in the Baltic proper (SD 24-32). According to spatially disaggregated landings figures (Figure 2), the actual boundary between the Kattegat-Belt-Sound stock and the Baltic stock may potentially be within the SD 24 rather than at the boundary between SD22 and SD 24; but this may cover too few catches to be considered manageable.

ICES (2012a, b) produced exploratory assessments of these alternative stock definitions. A combined assessment of the Skagerrak with the North Sea stock shows an upward scaling of the total biomass by about $15 \%$ but does not affect the general trends. Meanwhile, the assessment of Kattegat plaice together with Belt and Sound is more internally consistent than what was previously observed when it was assessed together with Skagerrak

In terms of improved scientific advice for management, ICES (2012c) gave specific consideration to the spatial structure in Skagerrak. A relative index of adult aggregation during spawning modified from Cardinale et al. (2011) was suggested by ICES (2012a, b) as a proxy for a SSB index for local plaice units, which showed different trends in dynamics

\section{Conclusion and future perspectives}

This multi-disciplinary work represents a milestone in a long and comprehensive endeavour, whose starting point was poor fisheries management and unresolved stock assessment issues. This unsustainable situation requires improved understanding and revision of basic biological hypotheses, which in turn would suggest alternative approaches to fisheries management. An important step forward has been achieved here in trying to infer the structure and connectivity of plaice populations in the transition area between the North Sea and the Baltic Sea based on available, but fragmented, knowledge. A complex picture of partly overlapping and interlinked populations with variable growth patterns has been implied from the assembled data, supporting the idea that the area IIIa cannot be considered and assessed as an isolated stock. Pragmatic approaches are now being implemented on an interim basis, as a first step towards sustainable management of the plaice fishery in the Skagerrak-Kattegat area.

New scientific analyses are currently being launched to better inform the origin of catches, through analyses of otolith shape and genetic markers in combination with hydrographical models (Gürkan et al., 2013). It is also hypothesised that the apparent contradictions in the observed lack of genetic differentiation for plaice compared to other fish stocks may be due to the choice of genetic markers in the various studies (potentially combined 
with inappropriate sampling design). As a tool, genetic markers have evolved towards targeting genes subject to environmental selection. Such markers may differentiate faster even under relatively high levels of migration (Nielsen et al. 2009). Thus, new findings of low but significant levels of population structuring or genetic isolation by distance may have strong implications for interpretation of evolutionary separation, migration rates and associated population based management (Reiss et al. 2009). Therefore, the ongoing analyses of plaice genetics in the transition area could potentially shed new light on the structuring of populations. Such information will allow disentangling the effect of genetic structuring from environment forcing in the growth patterns, potentially providing quantitative information on the degree of mixing of the various components and more accurate assessment of the status of these.

\section{Acknowledgements}

The work from DTU Aqua and DFPO authors has been mainly financed by the EFF project "Certified sustainability of Danish Fisheries". This support is gratefully acknowledged. The authors wish also to thank Barbara Schoute at the ICES secretariat for her support and help in integrating the scientific results into operational advice, as well as the monitoring group at DTU Aqua for providing data and practical knowledge.

\section{References}

Beverton, R.J.H, 1995. Spatial limitation of population size: The concentration hypothesis. Neth. J. Sea Res. 34, $1-6$.

Bierman, S.M., Dickey-Collas, M., van Damme, C.J.G., van Overzee, H.M.J., Pennock-Vos, M.G., Tribuhl, S.V., Clausen, L.A.W., 2010. Between-year variability in the mixing of North Sea herring spawning components leads to pronounced variation in the composition of the catch. ICES J. Mar. Sci. $67,885-896$.

Cardinale, M., Hagberg, J., Svëdang, H., Bartolino, V., Gedamke, T., Hjelm, J., Börjesson, P., Norén, F., 2009. Fishing through time: population dynamics of plaice (Pleuronectes platessa) in the Kattegat-Skagerrak over a century. Popul. Ecol., 52, 251-262.

Cardinale, M., Bartolino, V., Llope, M., Maiorano, L., Sköld M., Hagberg., J., 2011. Historical spatial baselines in conservation and management of marine resources. Fish Fish 12, 289-298. 
Clausen, L.A.W, Bekkevold, D., Hatfield, E.M.C., Mosegaard, H., 2007. Application and validation of otolith microstructure as a stock identification method in mixed Atlantic herring (Clupea harengus $\mathrm{L}$ ) stocks in the North Sea and western Baltic. ICES J. Mar. Sci. 64: 377-385.

Danielssen, D.S., Edler, L., Fonselius, S., Hernroth, L., Ostrowski, M., Svendsen, E., Talpsepp, L., 1997. Oceanographic variability in the Skagerrak and Northern Kattegat, May-June, 1990. ICES J. Mar. Sci. 54, 753773.

Engelhard, G.H., Pinnegar, J.K., Kell, L.T., Rijnsdorp, A.D., 2011. Nine decades of North Sea sole and plaice distribution. ICES J. Mar. Sci. 68, 1090-1104.

Gibson, R.N., Pihl, L., Burrows, M.T., Modin, J., Wennhage, H., Nickell, L.A, 1998. Diel movements of juvenile plaice Pleuronectes platessa in relation to predators, competitors, food availability and abiotic factors on a microtidal nursery ground. Mar. Ecol. Prog. Ser. 165, 145-159.

Gibson, R.N., 1999. The ecology of the early life stages of the plaice, Pleuronectes platessa L.: A review. Tohoku National Fisheries Research Institute 17-50.

Gürkan, Z., Christensen, A., Maar, M., Møller, E.F., Madsen, K.S., Munk, P., Mosegaard, H., 2013. Spatiotemporal dynamics of growth and survival of Lesser Sandeel early life-stages in the North Sea: Predictions from a coupled individual-based and hydrodynamic-biogeochemical model. Ecol. Model., 250, 294-306.

Hemmer-Hansen, J.H., Nielsen, E.E., Grønkjær, P., Loeschcke, V., 2007. Evolutionary mechanisms shaping the genetic population structure of marine fishes; lessons from the European flounder (Platichthys flesus L.). Mol. Ecol. 16, 3104-3118.

Hilborn, R., Quinn, T. P., Schindler, D. E., Rogers, D. E. 2003. Biocomplexity and fisheries sustainability. Proc. Natl. Acad. Sci. USA 100, 6564-6568.

Hoarau, G., Rijnsdorp, A.D., Van Der Veer, H.W., Stam, W.T., Olsen, J.L., 2002. Population structure of plaice (Pleuronectes platessa L.) in northern Europe: Microsatellites revealed large-scale spatial and temporal homogeneity. Mol. Ecol. 11, 1165-1176.

Hoarau, G., Piquet, A.M.T., van der Veer, H.W., Rijnsdorp A.D., Stam, W., Olsen, J.L., 2004. Population structure of plaice (Pleuronectes platessa L.) in northern Europe: a comparison of resolving power between microsatellites and mitochondrial DNA data. J. Sea Res. 51, 183-190. 
Hoarau, G., Boon, E., Jongma, D.N. Ferber, S., Palsson, J., Van Der Veer, H.W., Rijnsdorp, A.D., Stam, W.T., Olsen, J.L., 2005. Low effective population size and evidence for inbreeding in an overexploited flatfish, plaice (Pleuronectes platessa L.). Proc. Roy. Soc. Lond. B Biol. Sci. 272, 497-503.

Hufnagl, M., Peck, M.A., Nash, R.D., Pohlmann, T., Rijnsdorp, A.D.,2012. Changes in potential North Sea spawning grounds of plaice (Pleuronectes platessa L.) based on early life stage connectivity to nursery habitats.

Hunter, E., Metcalfe, J.D., Arnold, G.P., Reynolds, J.D., 2004. Impacts of migratory behaviour on population structure in North Sea plaice. J. Anim. Ecol. 73, 377-385.

ICES, 2006. Report of the Working Group on the Assessment of Demersal Stocks in the North Sea and Skagerrak (WGNSSK). ICES CM 2011/ACFM:09.

ICES, 2010. Report of the ICES Advisory Committee 2010. ICES Advice, 2010. Book 6, 309 pp.

ICES, 2011a. Report of the Working Group on the Assessment of Demersal Stocks in the North Sea and

ICES, 2011b. Report of the Workshop on the Implications of Stock Structure (WKISS), 5-7 April 2011, ICES

ICES, 2012a. Report of the Working Group on the Assessment of Demersal Stocks in the North Sea and pp.

ICES, 2012b. Report of the Workshop on the Evaluation of Plaice Stocks (WKPESTO), 28 February - 1 March 2012, ICES Headquarters, Copenhagen. ICES CM 2012/ACOM:32. 59 pp.

ICES, 2012c. Special request Advice June 2012. Joint EU-Norway request on management measures for plaice in the Skagerrak. ICES Advice, 2012. Book 6 
Johansen, A.C., 1912. Rødspættefiskeriet i Bælthavet (Plaice fisheri i the Belt Sea). Skr. Kommn. Havunders. 7. In Danish.

Kell, L.T., Scott, R., Hunter, E., 2004. Implications for current management advice for North Sea plaice: Part I. Migration between the North Sea and English Channel. J. Sea. Res. 51, 287-299.

Kell, L.T., Dickey-Collas, M., Hintzen, N.T., Nash, R.D.M., Pilling, G.M., Roel, B.A., 2009. Lumpers or splitters? Evaluating recovery and management plans for metapopulations of herring. ICES J. Mar. Sci. 66, 1776-1783.

Limborg, M., Pedersen, J.S., Hemmer-Hansen, J., Tomkiewicz, J., Bekkevold, D., 2009. Genetic population structure of European sprat (Sprattus sprattus L.): differentiation across a steep environmental gradient in a small pelagic fish. Mar. Ecol. Prog. Ser. 379, 213-224.

Metcalfe, J.D., 2006. Fish population structuring in the North Sea: understanding processes and mechanisms from studies of the movements of adults. J. Fish Biol. 69, 48-65.

Molander, A.R, 1923. Några result av märkningar och tillväxtundersökningar av rödspotta i Bohuslänska fjordar (Some results of tagging and growth investigations of plaice in fjords in the county of Bohuslän). Svensk Fiskeri-tidskrift 32:101-114. In Swedish.

Molander, A.R., 1944. Rödspotta och torsk i södra Kattegatt (Plaice and cod in the southern Kattegat). Meddelanden från Svenska Hydrografisk-biologiska Kommissionen. Biologi I. 23 pp. In Swedish.

Munk., P., Fox, C.J., Bolle, L.J., van Damme, C.J.G., Fossum, P., Kraus, G., 2009. Spawning of North Sea fishes linked to hydrographic features. Fish. Oceanogr. 18, 458-469.

Nielsen, E., Bagge, O., 1985. Preliminary investigations of 0-group and 1-group plaice surveys in the Kattegat in the period 1950-84. ICES CM 1985/G:19, 34 pp.

Nielsen, E., Bagge, O., MacKenzie, B.R., 1998. Wind-induced transport of plaice (Pleuronectes platessa) early life-history stages in the Skagerrak-Kattegat. J. Sea Res. 39, 11- 28.

Nielsen, E., Støttrup, J.G., Heilmann, J., MacKenzie, B.R., 2004a. The spawning of plaice Pleuronectes platessa in the Kattegat. J. Sea Res. 51, 219-228 
Nielsen, E.E., Nielsen, P.H., Meldrup, D., Hansen, M.M., 2004b. Genetic population structure of turbot (Scophthalmus maximus L.) supports the presence of multiple hybrid zones for marine fishes in the transition zone between the Baltic Sea and the North Sea. Mol. Ecol. 13, 585-595.

Nielsen, E.E., Hemmer-Hansen, J., Larsen, P.F., Bekkevold, D., 2009. Population genomics of marine fishes: identifying adaptive variation in space and time. Mol. Ecol. 18, 3128-3150.

Nissling, A., Westin, L., Hjerne, O., 2002. Reproductive success in relation to salinity for three flatfish species, dab (Limanda limanda), plaice (Pleuronectes platessa), and flounder (Pleuronectes flesus), in the brackish water Baltic Sea. ICES J. Mar. Sci. 59: 93-108.

Pihl, L., 1990. Year-class strength regulation in plaice (Pleuronectes platessa L.) on the Swedish west coast. Hydrobiol. 195, 79-88.

Pihl, L., Modin, J., Wennhage, H., 2000. Spatial distribution patterns of newly settled plaice (Pleuronectes platessa L.) along the Swedish Skagerrak archipelago. J. Sea Res. 44, 65-80.

Poulsen, E.M., 1939. On the migrations and racial character of the plaice. Danish Biol. Sta. XLIII, 1938,78 pp.

Reiss, H., Hoarau, G., Dickey-Collas, M., Wolf, W.J., 2009. Genetic population structure of marine fish: mismatch between biological and fisheries management units. Fish Fish. 10, 361-395.

Rijnsdorp, A.D., 1989. Maturation of male and female North Sea plaice (Pleuronectes platessa L.). ICES J. Mar. Sci. $46,35-51$.

Rijnsdorp, A.D., van Beek, F.A., Flatman, S., Millner, R.M., Riley, J.D., Giret, M., de Clerck, R., 1992. Recruitment of sole stocks, Solea solea (L.) in the northeast Atlantic. Neth. J Sea Res. 29, 173-192.

Simpson, A.C., 1959. The spawning of the plaice (Pleuronectes platessa) in the North Sea. Fish. Invest. Ser. II XXII, 7, $111 \mathrm{pp}$.

Sinclair, M., 1988. Marine Populations: An Essay on Population Regulation and Speciation. University of Washington Press. 252 pp.

Taylor, N., Fox, C.J., Bolle, L., Dickey-Collas, M., Fossum, P.G.K, Munk, P., Rolf, N., Van Damme, C., Vorbach, M., 2007. Results of the spring 2004 North Sea ichthyoplankton surveys. ICES Coop. Res. Rep., 285. 
Trybom, F, 1905. Märkning af rödspättor vid Sveriges vestkust 1902 och 1903 (Tagging of plaice on the west coast of Sweden 1902 and 1903). Meddelanden från Svenska Hydrografisk-biologiska Kommissionen 1-7. in Swedish.

Trybom, F, 1908. Svenska rödspättemärkningar och mätningar 1904 and 1905 (Swedish tagging of plaice and measurements 1904 and 1905). Meddelanden från Svenska Hydrografisk-biologiska Kommissionen 1-14. in Swedish.

Trybom, F, 1911. Svenska rödspättemärkningar 1909, med tillägg från äldre märkningar (Swedish tagging of plaice 1909, with supplement for older taggings). Meddelanden från Svenska Hydrografisk-biologiska

Ulmestrand, M, 1992. The geographical distribution, size composition and maturity stages of plaice Pleuronectes platessa (L.) during spawning season in the Skagerrak and Kattegat. Medd. Havsfiskelab., 325 (1992) $8 \mathrm{pp}$.

Van Banning, P., de Veen, J.F., van Leeuwen P.I., 1978. The myxosporidian parasite Myxobolus aeglefini Auerbach 1906, and its use as a parasitological tag for plaice of the eastern North Sea. ICES CM 1978/G:48. 22

van der Veer, H.W., 1986. Immigration, Settlement, and density-dependent mortality of a larval and early postlarval 0-group plaice (Pleuronectes platessa) population in the Western Wadden Sea. Mar. Ecol.-Prog. Ser. 29, 223-236.

van der Veer, H.W., Berghahn, R., Miller, J.M., Rijnsdorp, A.D., 2000. Recruitment in flatfish, with special emphasis on North Atlantic species: Progress made by the flatfish Symposia. ICES J. Mar. Sci. 57, 202-215. 
512 Wennhage, H., Pihl, L., Stål, J., 2007. Distribution and quality of plaice (Pleuronectes platessa) nursery grounds 513 on the Swedish west coast. J Sea Res. 57, 218-229.

514

515 Ying, Y., Chen, Y., Lin, L., and Gao, T., 2011. Risks of ignoring fish population spatial structure in fisheries 516 management. Can. J. Fish. Aquat. Sci. 68, 2101-2120. 
517

518

519

520

521

522

523

524

525

526

527

528

529

530

531

532

533

534

535

536

537

538

539

540

541

542

543

\section{Figures caption}

Figure 1. Hydrographical map of the area with average surface salinity, depth and currents (Yellow: Baltic current, Dark blue: North jutland current , Azure: Skagerrak costal current). Salinity data from DHI. Currents redrawn from Danielssen et al. (1997). The black straight lines delimitate the management areas.

Figure 2. Danish and Swedish plaice landings in 2009. Top: By ICES rectangle, all vessels included. Bottom: by 5*5 km grid, including the most spatially detailed information available (Sweden: logbooks information by haul, all vessels. Denmark: logbooks crossed with VMS data, vessels above fifteen meters; see Supplementary Online Material for further explanation). Black lines show boundaries of IIIa sub-areas.

Figure 3. Danish plaice landings by gear in Kattegat (Dashed line), Skagerrak (Plain line) and Central North Sea (Dotted line).

Figure 4 Proportion (\%) of historical recaptures corrected for the differences in recapture probability between areas, Danish tagging data 1903-1964. Top: all tags. Bottom: tags recaptured more than one year after the release. Black: Residency. Grey: migration towards Baltic Sea. white: migration towards North Sea.

Figure 5: Age-Length Keys and fitted Von Bertalanffy curves by sex and area, Danish harbour samples and IBTS data 2005-2010. (a) Females Skagerrak, (b) Females Kattegat, (c) Males Skagerrak, (d) Males Kattegat, (e) All four fitted Von Bertalanffy plotted together. Grey areas : 95\% confidence intervals of parameters estimates.

Figure 6: Average and fitted maturity by area, IBTS data 2005-2010 Diamonds and dashed line: Kattegat. Triangles and plain line : Skagerrak. Grey areas : 95\% confidence intervals of parameters estimates. 


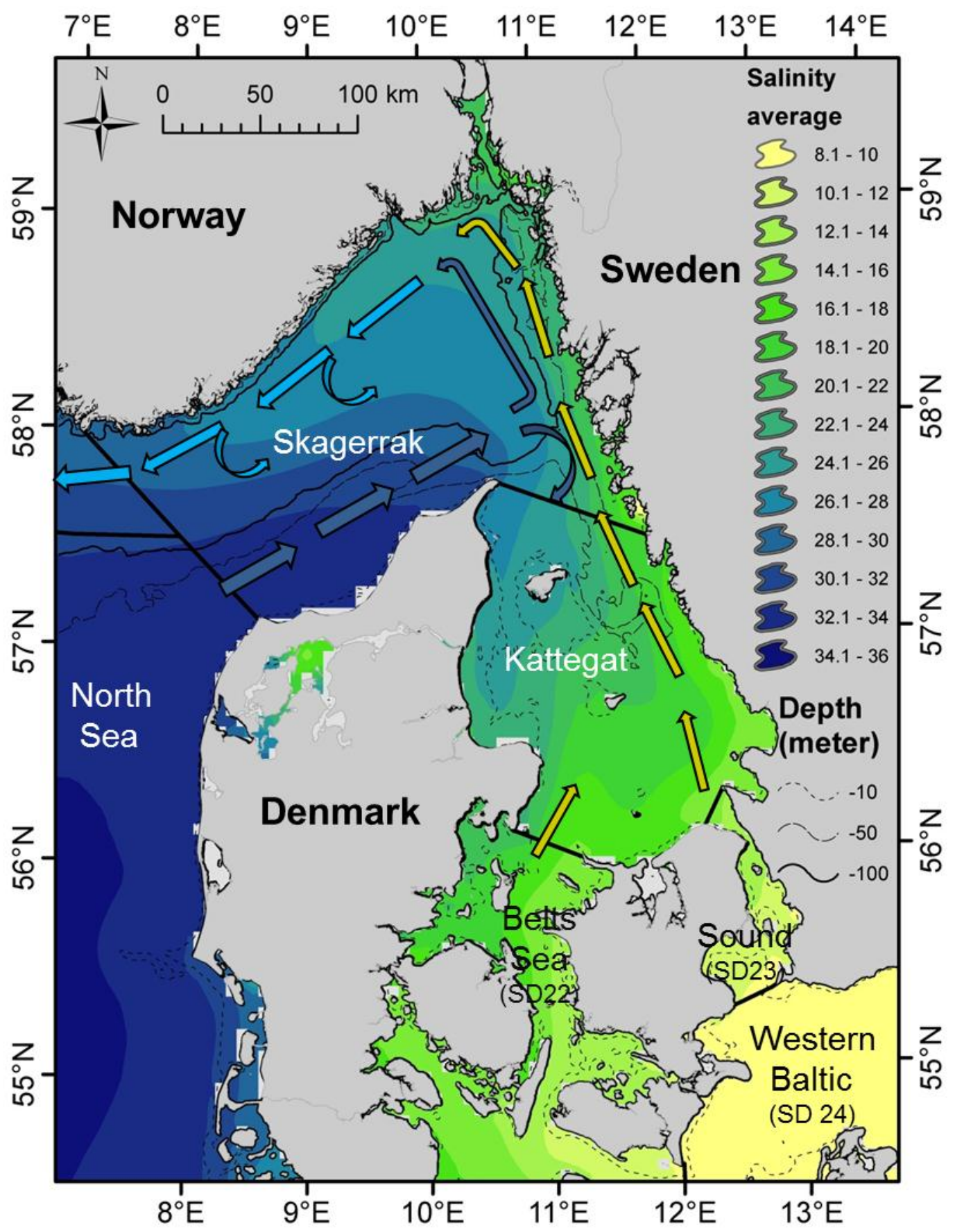

Figure 1. 
551
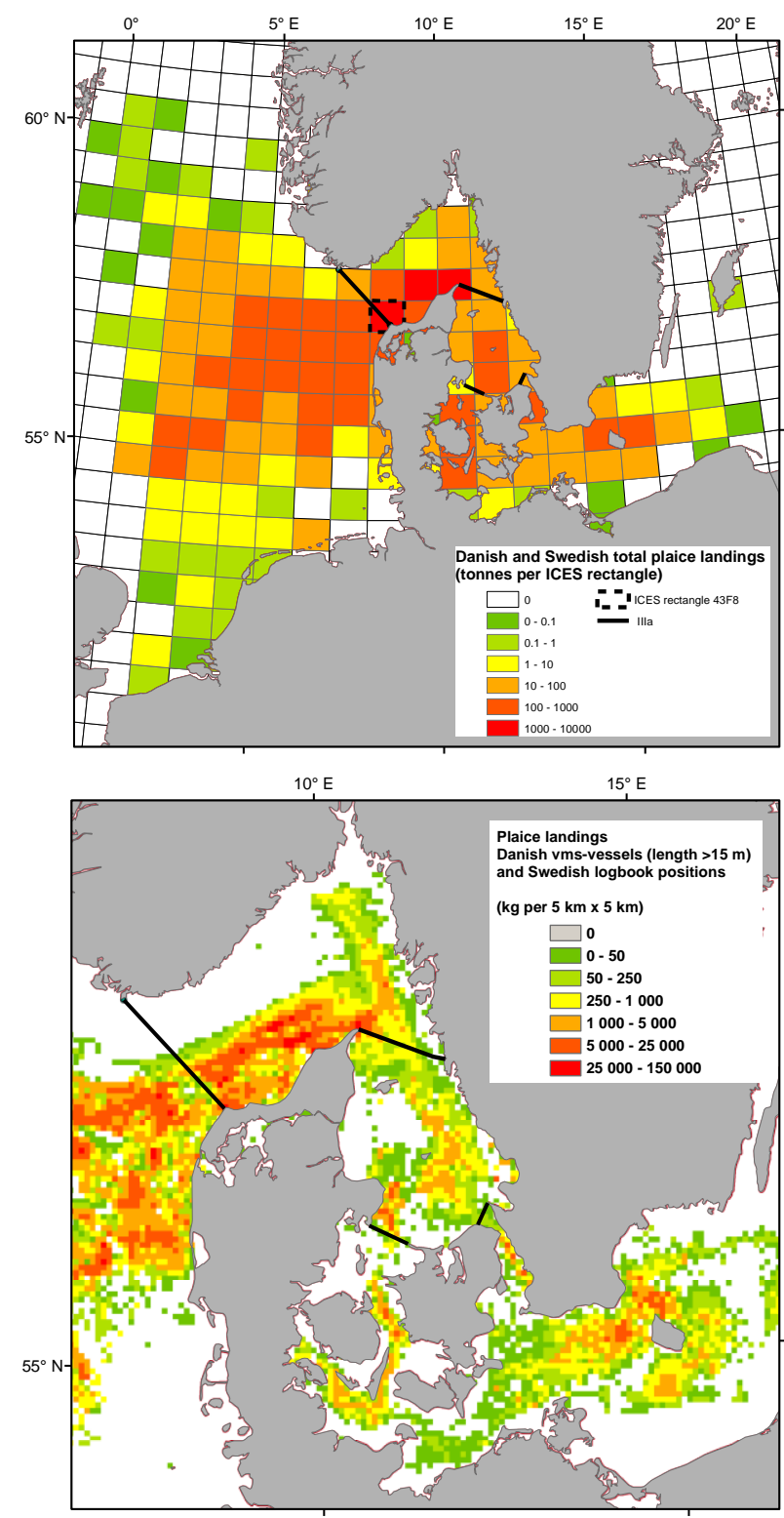

552

553

554

Figure 2.

555 


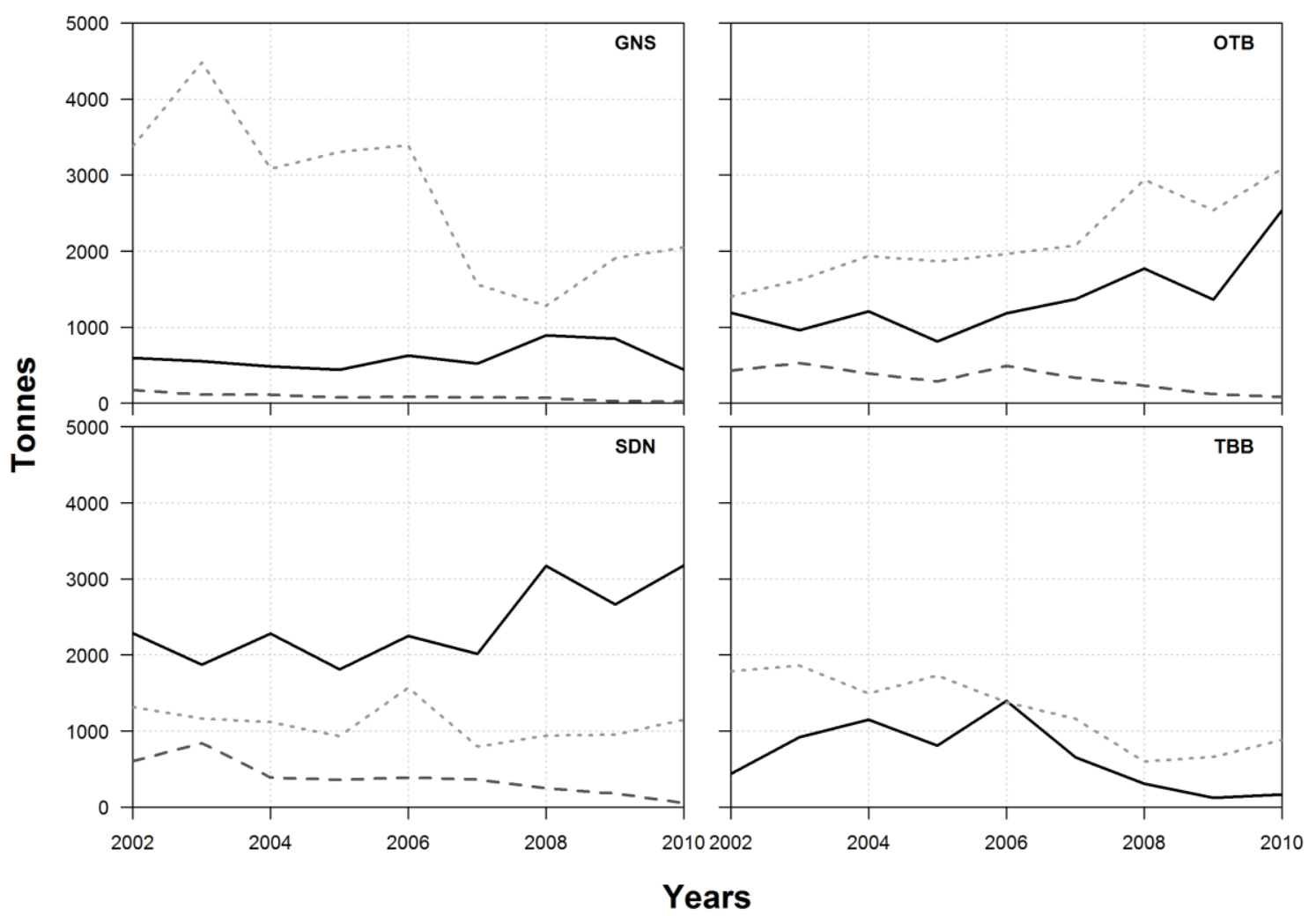

556

557 Figure 3. 


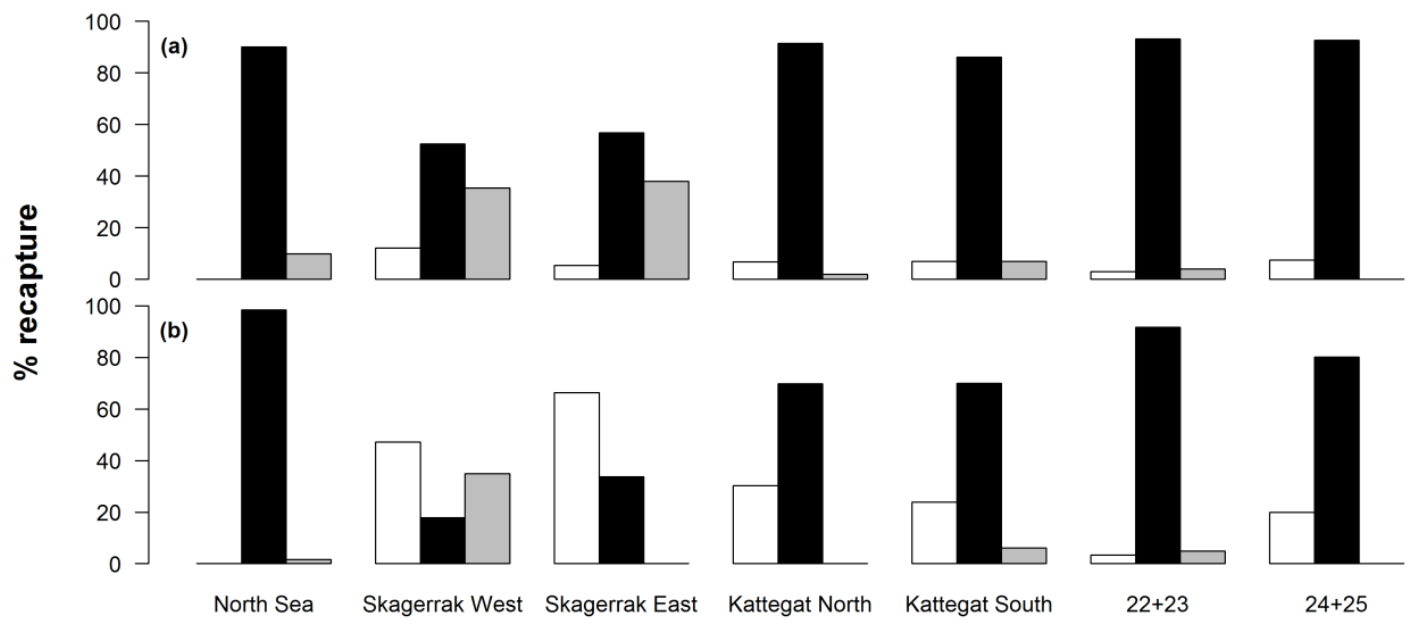

Figure 4 

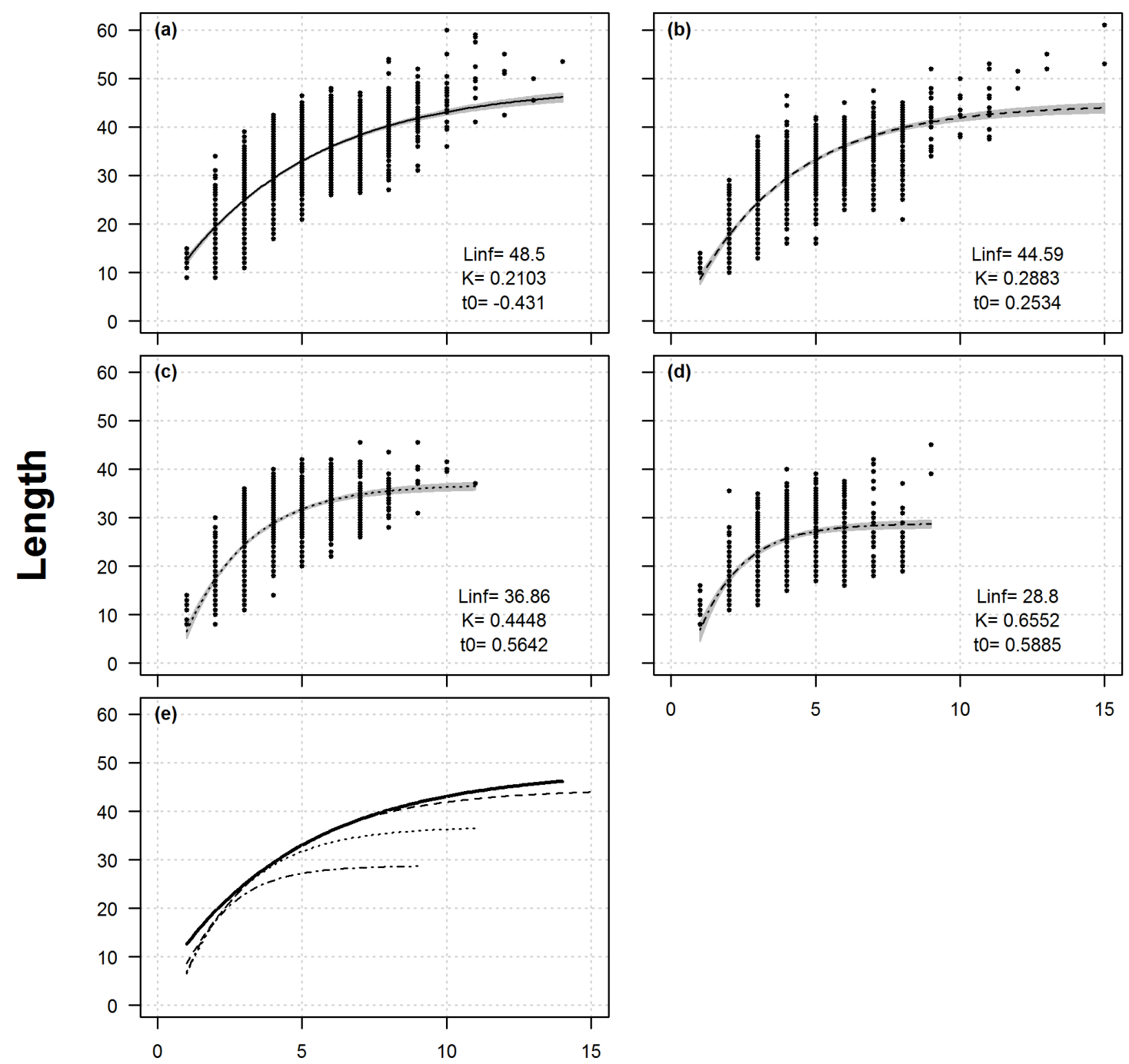

Age

565

Figure 5 


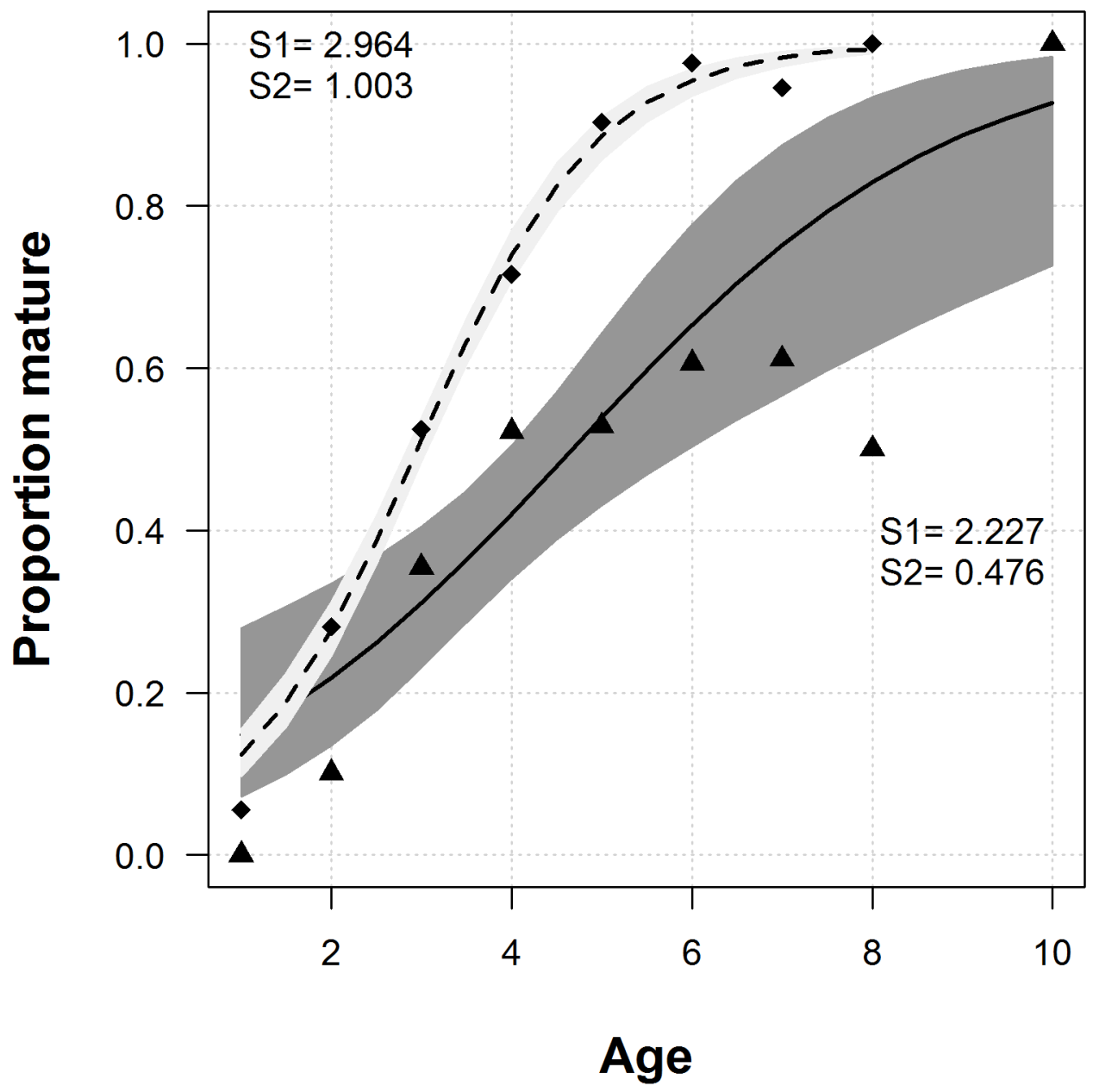

569

$570 \quad$ Figure 6

571 


\section{Supplementary On Line Material}

Supplementary data analyses were performed using recent fisheries data (2005-2010) including 1) Danish harbour sampling, 2) Danish and Swedish logbooks data and 3) survey data. The various data sources are briefly described, and detailed results are provided on online supplementary information.

\section{Fishery statistics}

Commercial landings as reported through logbooks and sale slips are the primary source of information used in stock assessment, and their reliability is crucial. Tonnage information in logbooks is automatically crossedchecked with sale slips, therefore the reported quantities are considered reliable. Paper logbooks can however be subject to important area misreporting, driven for example by differences in available fishing opportunities and regulations across management areas. Misreporting in the Danish logbooks between the area IIIa and adjacent waters was suspected to have occurred in the past for a number of species (e.g. ICES, 2010b). Logbook data were therefore scrutinised for similar issues for plaice, considering that most landings in area IIIa are reported at the edge of the North Sea (Figure 2; See also ICES (2011a) for the landings distribution by area and country). Noticeably, ICES rectangle 43F8, where up to $40 \%$ of Skagerrak landings are reported, is administratively split between both management areas, and misreporting in this particular area could potentially have large consequences. The validity procedure included a cross-check of logbooks data since 2005 with Vessel Monitoring System (VMS) data following the merging method developed by Bastardie et al. (2010) and Hintzen et al. (2012), allowing quantifying the amount of plaice misreporting (Gatti, unpublished ${ }^{1}$ ). For the vessels smaller than fifteen meters (more than $45 \%$ of the Danish plaice landings in area IIIa) for which no VMS are available, reported landing areas were checked against the departure harbour. Overall, no systematic area misreporting was observed for the period considered, and the mismatch between both data sources seemed to have declined over time (Gatti, unpublished). Although the possibility of area misreporting during the 1980 and 1990s cannot be ruled out, it is unlikely that this source of uncertainty is a significant factor of inconsistency in the data, and therefore the Danish logbooks can be considered to be sufficiently reliable to describe actual fishing patterns.

Swedish data were compiled from Swedish logbooks. Positions are based on gear set-positions for each effort as reported by fishers on a haul-by-haul basis, and the overall quality is judged reliable. In addition, the fishery takes only place in the central part of area IIIa. Therefore, no further check of potential area misreporting was performed.

\section{Biological sampling data}

The Danish harbour sampling program samples plaice on a quarterly basis to construct Age-Length-Keys by commercial category and sub-area. Catch-at-age information for the area IIIa is available since 1978, and by

\footnotetext{
${ }^{1}$ Gatti, 2011. Source of uncertainties in the catch-at-age matrix of the Illa plaice stock. Bachelor internship report, Agrocampus Ouest,
} Rennes, France. Unpublished. 
area since 1984; But the analyses of age-length keys was restricted to the period 2005-2010, as for fisheries data (Gatti, unpublished). On average, around 8300 fish are aged annually, of which $35-45 \%$ originate from the Skagerrak and $15-25 \%$ from the Kattegat, the rest being taken primarily in the North Sea and Belt Sea. Due to a number of external, practical and financial considerations the harbour sampling is however slightly skewed towards the Easterly side of the fishery in IIIa (where major cod and Nephrops fisheries are), although most plaice landings originate from the more westerly areas (Figure 2).

\section{Survey data}

Plaice data from the NS IBTS (North Sea International Bottom Trawl Survey) were extracted from the ICES database DATRAS (http://datras.ices.dk/). Information on growth, sex and maturity was investigated for the period 2005 to 2010. In addition, the IBTS time series have been used do derive relative indices of spawning abundance in IIIa, as suggested by Cardinale et al. (2011). In comparison to that study that spanned over a century of survey data, the time series of spatial indices was here restricted to the time frame of IBTS data only (since 1974), and not smoothed for year to year variation.

\section{References}

Bastardie, F., Nielsen, J.R., Ulrich, C., Egekvist, J., Degel, H., 2010. Detailed mapping of fishing effort and landings by coupling fishing logbooks with satellite-recorded vessel geo-location. Fish. Res., 106, 41-53.

Cardinale, M., Bartolino, V., Llope, M., Maiorano, L., Sköld M., Hagberg., J., 2011. Historical spatial baselines in conservation and management of marine resources. Fish Fish 12, 289-298.

Hintzen, N.T., Bastardie, F., Beare, D., Piet, G.J., Ulrich, C., Deporte, N., Egekvist, J., Degel, H., 2012. VMStools: Open-source software for the processing, analysis and visualisation of fisheries logbook and VMS data. Fish. Res. 115-116:31-43.

ICES, 2010b. Report of the Workshop on procedures to establish the appropriate level of the mixed herring TAC (Spring Western Baltic (WBSS) and Autumn Spawning North Sea (NSAS) stocks) in Skagerrak and Kattegat (Division IIIa, 23 - 25 November, ICES Headquarters, Copenhagen. ICES CM 2010/ACOM:64. 63 pp.

ICES, 2011a. Report of the Working Group on the Assessment of Demersal Stocks in the North Sea and Skagerrak (WGNSSK), 4 - 10 May 2011, ICES Headquarters, Copenhagen. ICES CM 2011/ACOM:13. 1190 pp. 